\title{
Penerapan Pembelajaran Means Eand Analysis Untuk Meningkatkan Motivasi Belajar Pada Mata Pelajaran Matematika Siswa Kelas VI Madrasah Ibtidaiyah 2 Jombang
}

\author{
Khurin'In Ratnasari \\ Institut Agama Islam Al-falah As-suniyah Kencong Jember \\ Email : khurininratnasari@gmail.com
}

\begin{abstract}
Abstrak: Tujuan penelitian adalah mengetahui adanya peningkatan motivasi belajar siswa melalui Penerapan Pembelajaran Means Eand AnalysisPada Mata Pelajaran Matematika Siswa Kelas VI Madrasah Ibtidaiyah 2 Jombang. Jenis penelitian ini adalah penelitian tindakan kelas yang dilakukan secara kolaborasi antara peneliti dengan guru matematika. Subjek dalam penelitian ini adalah siswa kelas V1 MI Jombang - Jember. Metode pengumpulan data yang digunakan pada penelitian adalah metode observasi, metode tes, catatan lapangan dan dokumentasi. Teknik analisis data yang digunakan pada penelitian adalah reduksi, pemaparan data dan penarikan kesimpulan. Hasil penelitian ini adalah adanyapeningkatan motivasi belajar siswa melalui Penerapan Pembelajaran Means Eand Analysis yaitu:Kesiapan siswa mengikuti pelajaran pada siklus I 15 siswa $(65 \%)$ pada siklus II ada 24 siswa (94\%), Keaktifan siswa dalam pelajaran pada siklus I 5 Siswa (24\%)pada siklus II ada 15 siswa (60\%), Kesanggupan siswa dalam mengerjakan soal 10 siswa (55\%) pada siklus II ada 20 siswa (80\%), siswa yang memiliki kemampuan memahami masalah penelitian pada siklus I ada 10 siswa (55\%), pada siklus II ada 24 siswa (94\%), (b) Siswa yang memiliki kemampuan merencanakan pemecahan masalah siklus I ada 8 siswa (45\%), pada siklus II ada 20 siswa $(80 \%)$, (c) Siswa yang memiliki kemampuan melaksanakan pemecahan masalah pada siklus I ada 15 siswa (65\%), pada siklus II ada 25 siswa (100\% ).Berdasarkan uraian yang telah dikemukan di atas dapat disimpulkan bahwa penerapan model pembelajaran means ends analysis dapat meningkatkan motivasi belajar siswa dalam pelajaran matematika.
\end{abstract}

Kata kunci: Means ends analysis, dan motivasi belajar.

\section{Pendahuluan}

Proses pembelajaran merupakan salah satu unsur penting untuk mencapai keberhasilan dalam pembelajaran. Dalam proses pembelajaran itulah terjadi proses transformasi ilmu pengetahuan serta nilai-nilai. Ketika proses pembelajaran berlangsung, terjadi interaksi antara guru dengan siswa yang memungkinkan bagi guru untuk dapat mengenali karakteristik serta potensi yang dimiliki siswa. Demikian pula sebaliknya, pada saat pembelajaran siswa memiliki kesempatan untuk mengembangkan potensi yang dimilikinya sehingga potensi tersebut dapat dioptimalkan. oleh karenaitu, pendidikana bukan lagi memberikan stimulus akan tetapi usaha mengembangkan potensi yang dimiliki. Pengetahuan itu tidak diberikan, akan tetapi dibangun 
oleh siswa ( Wina Sanjaya, 2009: 102). Untuk dapat mengenali dan mengembangkan potensi siswa tentunyadalam proses pembelajaran perlu pembelajaran yang bersifat aktif. ${ }^{1}$

Pembelajaran tidak lagi berpusat pada guru tetapi berpusat pada siswa danguru hanya sebagai fasilitator serta pembimbing. Dengan demikian, siswa memiliki kesempatan yang luas untuk mengembangkan kemampuannya seperti mengemukakan pendapat, berpikir kritis, menyampaikan ide atau gagasan dan sebagainya. Belajar aktif sangat diperlukan oleh siswa untukmendapatkan hasil yang maksimal. Ketika siswa pasif, atau hanya menerima dari pengajar ada kecenderungan untuk melupakan apa yang telah diberikan pengajar (Hisyam Zaini, 2008: $\mathrm{XIV).2}$

Pada kenyataanya proses pembelajaran masih dominan terpusat padaguru, salah satu indikatornya yaitu pembelajaran masih dominan dengan metode ceramah dan siswa lebih banyak pasif, sebagai pendengar. Okezone.commemberitakan bahwa dalam menyampaikan penjelasan, guru diIndonesia terlalu panjang lebar. Selain itu, durasi pembelajaran selama 80 menit membuat guru kurang cermat dalam merancang pembelajaran. Tanpasadar itu sudah menjadi budaya guruguru di Indonesia. Kalau kita inginmengubah hal tersebut maka perlu dilakukan analisa alasan terjadinyapermasalahan tersebut.

Seperti pada pembelajaran pada umumnya, pembelajaran pada matapelajaran Matematika di MI juga masih dominan berpusatpada guru. Metode pembelajaran Matematika di MI lebih banyak menggunakan metode ceramah. Metode ini seringkali membuat proses pembelajaran menjadi membosankan.Dalam pembelajaran Matematika sering dijumpai guru hanyamenggunakan metode yang monoton, menyampaikan materi melalui ceramah, pemberian tugas dan mengerjakan LKS, sehingga pembelajaran kurang menarik. Sekolah juga masih ada kecenderungan guru dalam pembelajaran Matematika menggunakan cara konvensional atau tradisional, pembelajaran tidak berpusat pada peserta didik.

Sejalan dengan pernyataan di atas, dari hasil pengalaman PraktikPengalaman Lapangan (PPL) serta diskusi dengan guru mata pelajaran Matematika, diketahui bahwa pembelajaran Matematika di MI 2 Jombang lebih didominasi dengan metode ceramah. Padahal dalam sebuah penelitian menunjukan bahwadalam pembelajaran bergaya ceramah siswa kurang menaruh perhatian selama $40 \%$ dari seluruh waktu pembelajaran. Siswa dapat mengingat $70 \%$ dalam sepuluh menit pertama pembelajaran, sedangkan dalam sepuluh menit terakhirmereka hanya dapat mengingat 20\% materi pembelajaran. (Melvin L.Silberman, 2011: 24)3

${ }^{1}$ Sanjaya Wina, Kurikulum dan Pembelajaran(Jakarta: Kencana, 2009).

${ }^{2}$ Hisyam Zaini.2008 Srategi pembelajaran aktif. (Yogyakarta: Insan Mandiri).

${ }^{3}$ Melvin L. 2011. Siberman active Leraning 101 Cara belajar Siswa Aktif

(Bandung: Nusamedia) 
Berdasarkan hasil observasi serta diskusi dengan guru, di MI 2 Jombang diketahui bahwa penggunaan metode ceramah yangdominan menjadikan pembelajaran kurang menarik. Pembelajaran terkesanmembosankan dan siswa kurang termotivasi dalam belajar Matematika. Hal tersebut tampak dari sikap siswa kelas VI yang kurang memperhatikan pelajaran, bercerita dengan teman sebangku, mengantuk, bahkan ada siswa yang menggambar atau mengerjakan tugas mata pelajaranlain. Kondisi pembelajaran yang demikian tentu sangat tidak kondusif.

Proses pembelajaran yang membuat siswa merasa bosan berakibatpada rendahnya motivasi belajar siswa. Selain itu proses pembelajarantersebut kurang mendorong siswa untuk ikut serta berpartisipasi aktif dalam kegiatan pembelajaran. Dalam hal ini guru perlu menerapkan pembelajaranyang mampu meningkatkan motivasi belajar siswa sehingga diperoleh hasilbelajar yang optimal.

Motivasi merupakan salah satu hal penting dalam proses pembelajaran. Siswa yang memiliki motivasi tinggi tentunya akan bersemangat dalam pembelajaran dan sungguh-sungguh dalam belajarnya. Dengan adanya motivasi pula siswa yang memiliki kemampuan kurang akan bersemangat dalam belajar agar mampu bersaing dengan teman-temannya.

Motivasi belajaryang baik akan menumbuhkan iklim belajar yang baik pula sehingga tujuan pembelajaran dapat tercapai serta pembelajaran menjadi lebih berkualitas. Salah satu upaya yang dapat diterapkan untuk mengatasi rendahnya motivasi belajar siswa yaitu dengan menggunakan penerapan pembelajaranaktif.

Penerapan pembelajaran aktif memberikan kesempatan bagi siswa untukikut terlibat secara aktif. Dengan demikian, siswa dapat mengungkapkangagasan, ide, pendapat dan kreatifitasnya sehingga pembelajaran akan lebih menarik. Dengan siswa belajar aktif, siswa diajak untuk turut serta dalam proses pembelajaran, tidak hanya secara mental akan tetapi juga melibatkanfisik. Dengan cara ini biasanya siswa akan merasakan suasana yang lebih menyenangkan sehingga hasil belajar dapat dimaksimalkan.4

Berdasarkan latar belakang tersebut maka dipandang perlu untuk Berdasarkan latar belakang tersebut maka dipandang perlu untuk menerapkan pembelajaran yang menarik untuk meningkatkan motivasi belajar siswa kelas VI MIJombang Jember. dari uraian di atas, peniliti tertarik melakukan penelitian berjudul "Penerapan Pembelajaran Means Eand AnalysisUntukMeningkatkan Motivasi Belajar Pada Mata Pelajaran Matematika Siswa Kelas VI Madrasah Ibtidaiyah 2 Jombang” Tujuan Umum penelitian ini adalah "Apakah ada peningkatan motivasi belajar siswa melalui Penerapan Pembelajaran Means Eand AnalysisPada Mata Pelajaran Matematika Siswa Kelas VI Madrasah Ibtidaiyah 2 Jombang”.

${ }^{4}$ Hisyam Zaini.2008 Srategi pembelajaran aktif. (Yogyakarta: Insan Mandiri) 


\section{Means Ends Analysis (MEA)}

Secara etimologis, Means Ends Analysis (MEA) terdiri dari tiga unsure kata, yakni: Means berarti cara, End berarti tujuan, dan Analysis berarti analisis atau menyelidiki secara sistematis. Dengan demikian, MEA bisa diartikan sebagai strategi untuk menganalisis permasalahan melalui berbagai cara untuk mencapai tujuan akhir yang diinginkan.MEA juga digunakan sebagai salah satu cara untuk mengklarifikasi gagasan seseorang ketika melakukan pembuktian matematis.5

MEA adalah variasi dari pembelajaran dengan pemecahan masalah (problem solving). MEA merupakan metode pemikiran system yang dalam penerapannya merencanakan tujuan keseluruhan. Tujuan tersebut dijadikan dalam beberapa tujuan yang pada akhirnya menjadi beberapa langkah atau tindakan berdasarkan konsep yang berlaku. Pada setiap akhir tujuan, akan berakhir pada tujuan yang lebih umum.MEA merupakan strategi yang memisahkan permasalahan yang diketahui (problem state) dan tujuan tujuan yang akan dicapai (goal state) yang kemudian dilanjutkan dengan melakukan berbagai cara untuk mereduksi perbedaan yang ada di antara permasalahan dan tujuan. Means berarti alat atau cara bebeda yang bisa memecahkan masalah, sementara Ends berarti akhir tujuan dari masalah.

Dalam model pembelajaran Means Ends Analysis tujuan yang dicapai ada dalam cara dan langkah itu sendiri untuk mencapai tujuan yang lebih umum dan rinci sehingga dapat mengembangkan berpikir reflektif, kritis, logis, sistematis, dan kreatif pada pesrta didik. Langkahlangkah yang dilakukan pada metode pembelajaran Means Ends Analysis menuntut peserta didik mempunyai kemampuan untuk mengkomunikasikan ide dalam menganalisis sub-sub masalah dan dalam memilih strategi solusi, serta membimbing peserta didik untuk melaksanakan aspek pemecahan masalah. MEA juga digunakan sebagai salah satu cara untuk mangklarifikasi gagasan seseorang ketika melakukan pembuktian matematis.

\section{Ciri - Ciri Pembelajaran Means Ends Analysis}

Penggunaan model pembelajaran Means Ends Analysis (MEA) dapat lebih memotivasi peserta didik untuk saling bekerjasama, berpartisipasi aktif, dan menarik perhatian peserta didik dalam kegiatan pembelajaran, sehingga materi pelajaran yang dipelajari lebih mudah dipahami. Selain itu, dengan model pembelajaran Means Ends Analysis (MEA) peserta didik mampu meningkatkan kemampuan pemecahan masalah, mampu berpikir kreatif dan cermat sehingga memperoleh pengalaman belajar yang lebih bermakna dalam pembelajaransehingga dapat meningkatkan hasil belajar. ${ }^{6}$

\footnotetext{
${ }^{5}$ Miftahul Huda.2013. Model-Model Pengajaran dan Pembelajaran (Yogyakarta : Pustaka Belajar) 'Puspitasari, Itta Denny. 2012. Peningkatan Keterampilan Pemecaban MasalabBelajar Matematika Melalui Strategi Means Ends Analysis. (Surakarta: FKIP UMS)
} 
Model pembelajaran Means Ends Analysis (MEA) memberikan kesempatan kepada peserta didik belajar matematika dengan aktif mengkonstruksi pengetahuannya sendiri, dan dapat membantu peserta didik untuk dapat memahami dan menyelesaikan masalah matematis. Means Ends Analysis (MEA) adalah suatu model yang digunakan padapemecahan masalah dimana mencoba untuk mereduksi perbedaan antara current state of the problem (pernyataan sekarang dari suatu masalah)dan goal state (tujuan yang hendak dicapai).https://groups.google.com/forum/?fromgroups=\#!msg/pmt03/LL2hjGJHwtI/fBAKc B5FyPYJ ${ }^{7}$

Dalam model pembelajaran ini, peserta didik tidak akan dinilai berdasarkan hasil saja, namun berdasarkan proses pengerjaan. Selain itu peserta didik juga dituntut untuk mengetahui apa tujuan yang hendak dicapai atau masalah apa yang hendak diselesaikan dan memecahkan suatu masalah ke dalam dua atau lebih subtujuan dan kemudian dikerjakan berturut-turut pada masing-masing subtujuan tersebut.

Model pembelajaran Means Ends Analysis (MEA) ini lebih memusatkan pada perbedaan antara pernyataan dari suatu masalah (the current state of the problem) dengan tujuan yang hendak dicapai (the goal state). Maksudnya disini yaitu dalam proses pengerjaan soal oleh peserta didik, peserta didik tersebut mampu menemukan solusi dari soal tersebut dimana pada langkahlangkah pengerjaannya, peserta didik mampu melihat perbedaan antara masalah dan tujuan yang akan dicapai. Model pembelajaran ini lebih menekankan pada kemampuan peserta didik dalam memecahkan masalah.(Rusita.2011)

\section{Tinjauan Tentang Motivasi Belajar}

\section{Pengertian Motivasi Belajar}

Mc. Donald dalam Oemar Hamalik motivation is an energy changewithinthe person characterized by affective arousal and anticipatory goal reaction. Mengemukakan bahwa motivasi adalah perubahan energi dalam diriseseorang yang ditandai dengan timbulnya perasaan dan didahului dengan tanggapan untuk mencapai tujuan.Sedangkan menurut Smadi Suryabrata dalam Djalli motivasi adalah keadaan yang terdapat dalah diri seseorang yang mendorong untuk melakukan aktivitas tertentu guna mencapai suatu tujuan.Motivasi akan menyebabkan terjadinya suatu perubahan energi yang ada pada diri manusia, sehingga akan bergayut dengan persoalan

\footnotetext{
${ }^{7}$ Herdian. 2009. "Model Pembelajaran MEA (Means-Ends Analysis)". https://groups.google.com/forum/?fromgroups=\#!msg/pmt03/LL2hjGJHwtI/fBAKcB5FyPYJ Diakses tanggal 22 Oktober 2012

${ }^{8}$ Rusfita, Aulia Faradian .2011. Penerepan Model Pembelajaran Means Ends Analysis untuk. Meningkatkean Minat dan Hasil Belajar pada Keliling dan Luas Persegi Panjang. Skripsi. Surakarta: FKIP UMS
} 
gejala kejiwaan, perasaan dan juga emosi, untuk kemudian bertindak atau melakukan sesuatu. Semua ini didorong karena adanya tujuan, kebutuhan atau keinginan.9

Motivasi dapat juga dikatakan serangkaian usaha untuk menyediakan kondisi - kondisi tertentu, sehingga seseorang mau dan ingin melakukan sesuatu, dan bila ia tidak suka, maka akan berusaha untuk meniadakan atau mengelakkan perasaan tidak suka itu. Jadi motivasi dapat dirangsang oleh factor dari luar tetapi motivasi itu adalah tumbuh di dalam diri seseorang. Peserta didik yang motivasi berprestasinya tinggi hanya akan mencapai prestasi akademis yang tinggi apabila rasa takut akan kegagalan lebih rendah dari pada keinginannya untuk berhasil dan tugas tugas didalam kelas cukup memberi tantangan, tidak terlalu mudah tetapi juga tidak terlalu suka, sehingga memberi kesempatan untuk berhasil.

\section{Fungsi Motivasi Belajar}

1. Motivasi mendorong timbulnya kelakuan dan mempengaruhi serta mengubah kelakuan, sehingga fungsi motivasi meliputi berikut ini:

2. Mendorong timbulnya kelakuan atau suatu perbuatan. Tanpa motivasi maka tidak akan timbul sesuatu perbuatan seperti belajar.

3. Motivasi berfungsi sebagai pengarah. Artinya mengarahkan perbuatan kepencapaian tujuan yang diinginkan.

4. Motivasi berfungsi sebagai penggerak. Yakni berfungsi sebagai mesin bagi mobil. Besar kecilnya motivasi akan menentukan cepat atau lambatnya suatu pekerjaan

5. Di samping itu, ada juga fungsi - fungsi lain. Motivasi dapat berfungsi sebagai pendorong usaha dan pencapaian prestasi. Adanya motivasi yang baik dalam belajar akan menunjukkan hasil yang baik. Intensitas motivasi seorang peserta didik akan sangat menentukan tingkat pencapaian prestasi belajar.10

6. Nilai Motivasi dalam Pengajaran

7. Menjadi tanggung jawab guru agar pengajaran yang diberikan berhasil dengan baik. Khairani berpendapat Keberhasilan ini banyak bergantung pada usaha guru membangkitkan motivasi belajar. Dalam garis besarnya motivasi mengandung nilai nilai sebagai berikut ini:11

8. Motivasi menentuka tingkat berhasil atau gagalnya perbuatan belajar peserta didik. Belajar tanpa adanya motivasi kiranya sulit untuk berhasil.

${ }^{9}$ Djaali, H. 2008. Psikologi Pendidikan.(Bumi Aksara: Jakarta)

\footnotetext{
${ }^{11}$ Khairani, Makmun. 2013. Psikologi Belajar. Yogyakarta: Aswaja Pressindo.
} 
9. Pengajaran yang bermotivasi pada hakikatnya adalah pengajaran yang disesuaikan dengan kebutuhan, dorongan, motif, minat yang ada pada peserta didik. Pengajaran yang demikian sesuai dengan tuntutan demokrasi dalam pendidikan.

10. Pengajaran yang bermotivasi menuntut kreativitas dan imajinasi guru untuk berusaha secara sungguh - sungguh mencari cara - cara yang relevan dan sesuai guna membangkitkan dan memelihara motivasi belajar peserta didik.

11. Guru senantiasa berusaha agar peserta didik akhirnya memiliki self motivation yang baik. Berhasil atau gagalnya dalam membangkitkan dan menggunakan motivasi dalam pengajaran erat pertaliannya dengan pengaturan disiplin kelas. Kegagalan dalam hal ini mengakibatkan timbulnya masalah disiplin di dalam kelas.

12. Asas motivasi menjadi salah satu bagian yang integral dari pada asas mengajar. Penggunaan motivasi dalam mengajar buku saja melengkappi prosedur mengajar, tetapi juga menjadi factor yang menentukan pengajaran yang efektif. 12Demikian penggunaan asas motivasi adalah sangat esensial dalam proses belajar mengajar.

\section{Macam-Macam Motivasi}

Berbicara tentang macam - macam motivasi dapat dilihat dari berbagai sudut pandang. Dengan demikian, motivasi itu sangat bervariasi yakni:

1. Motivasi dilihat dari dasar pembentukannya antara lain; motivasi bawaan, yakni motivasi yang dibawa sejak lahir, jadi motivasi itu ada tanpa dipelajari, dan motivasi yang dipelajari, yakni motivasi yang timbul karena dipelajari.

2. Jenis motivasi menurut pembagian dari Woodworth dan Marquis antara lain; motif atau kebutuhan organis, motivasi darurat, dan motivasi objektif.

3. Motivasi jasmaniah dan rohaniah antara lain; momen timbulnya alasan, momen pilih, momen putusan, momen terbentuknya kemauan

4. Motivasi intrinsik dan ekstrinsik antara lain; motivasi intrinsic dan motivasi ekstrinsik.

\section{Cara Menggerakkan Motivasi Belajar Peserta Didik}

Guru dapat menggunakan berbagai cara untuk menggerakkan atau membangkitkan motivasi belajar peserta didik, yakni sebagai berikut: ${ }^{13}$

\footnotetext{
12 Uno,B Hamzah.2010. Teori Motivasi \& Pengukuranya (Jakarta : Bumi Aksara)

${ }^{13}$ Djamarah,Syaiful Bahri.2015.Psikologi Belajar. (Jakarta: Rineka Cipta)
} 
- Memberi angka, yang merupakan simbol dari kegiatan belajar, banyak peserta didik yang belajar hanya untuk mendapatkan angka/nilai yang baik. Biasanya peserta didik yang dikejar adalah nilai ulangan atau nilai-nilai dalam raport.

- Pujian, sebagai hadiah yang positif yang sekaligus memberikan motivasi yang baik. Dengan pujian yang tepat akan memupuk suasana yang menyenagkan dan mempertinggi gairah belajar serta sekaligus akan membangkitkan harga diri.

- Hadiah, hadiah juga dapat digunakan sebagai motivasi, tetapi tidak selalu demikian. Karena hadiah untuk pekerjaan mungkin tidak akan menarik bagi seseorang yang tidak senang dan tidak berbakat dalam pekerjaan tersebut.

- Keterlibatan diri, keterlibatan diri ini menumbuhkan kesadaran pada peserta didik agar merasakan pentingnya tugas dan menerimanya sebagai tantangan sehingga kerja keras dengan mempertaruhkan harga diri, adalah sebagai salah satu bentuk motivasi yang sangat penting.

- Persaingan, persaingan dapat juga digunakan sebagai motivasi, baik persaingan individual atau persaingan kelompok dapat meningkatkan prestasi belajar peserta didik.

- Memberi ulangan, para peserta didik akan giat belajar apabila mengetahui akan adanya ulangan. Oleh karena itu, member ulangan ini juga merupakan sarana motivasi.

- Mengetahui hasil, dengan mengetahui hasil apalagi terjadi kemajuan akan mendorong peserta didik untuk giat belajar. Semakin mengetahui bahwa grafik hasil belajar meningkat, maka ada motivasi pada diri peserta didik untuk terus belajar, dengan suatu harapan hasilnya terus meningkat.

- Hukuman, sebagai hadiah yang negatif tetapi kalau diberikan secara tepat dan bijak bisa menjadi alat motivasi. Oleh karena itu, guru harus memahami prinsip - prinsip pemberian hukuman.

- Hasrat untuk belajar, berarti ada unsur kesengajaan, ada maksud untuk belajar. Hasrat untuk belajar berarti pada diri anak itu memang ada motivasi untuk belajar, sehingga sudah barang tentu hasilnya akan lebih baik.

- Minat, motivasi muncul karena adanya kebutuhan, begitu juga minat sehingga tepatlah kalau minat merupakan motivasi yang pokok, proses belajar itu akan berjalan lancar apabila disertai dengan minat. 
- Tujuan yang diakui, rumusan tujuan yang diakui dan diterima baik oleh peserta didik akan merupakan alat motivasi yang sangat penting. Sebab dengan memahami tujuan yang harus dicapai, karena dirasa sangat berguna dan menguntungkan, maka akan timbul gairah untuk terus belajar.

\section{Faktor Yang Mempengaruhi Motivasi Belajar Peserta Didik}

Beberapa faktor yang mempengaruhi motivasi belajar antara lain:

a) Eksternal, yakni faktor dari luar situasi belajar individu, seperti ijazah, tingakatan hadiah, medali, dan persaingan yang bersifat negative seperti sarcasm, ridicule, dan hukuman. Motivasi ini tetap diperlukan disekolah,sebab pengajaran di sekolah tidak semuanya menarik minat peserta didik atau sesuai dengan kebutuhan peserta didik. Seringkali para peserta didik belum memahami untuk apa ia belajar hal - hal yang diberiakn di sekolah. Karena itu, motivasi terhadap pelajaran itu perlu dibangkitkan oleh guru sehingga peserta didik mau dan ingin belajar. Usaha yang dapat dikerjakan guru memang banyak, dan karena itu, di dalam memotivasi peserta didikkita tidak akan menentukan suatu formula tertentu yang dapat digunakan setiap saat oleh guru.

b) Internal, yakni faktor dari dalam diri individu, yang tercakup di dalam situasi belajar dan menemui kebutuhan dan tujuan - tujuan peserta didik. Motivasi ini sering disebut juga motivasi murni. Motivasi yang sebenarnya yang timbul dalam diri peserta didik sendiri tanpa pengaruh dari luar, seperti keinginan untuk mendapat ketrampilan tertentu, mengembangkan sikap untuk berhasil, memperoleh informasi, dan lain - lain. Dalam hal ini pujian atau sejenisnya tidak diperlukan karena tidak akan menyebabkan peserta didik bekerja

\section{Metode Penelitian}

Penelitian ini merupakan penelitian tindakan kelas (classroom actionresearch). Penelitian tindakan dalam bidang pendidikan yang dilaksanakandalam kawasan kelas dengan tujuan untuk memperbaiki dan meningkatkan kualitas pembelajaran. Secara singkat PTK dapat didefinisikan sebagai suatu bentuk penelaahan penelitian yang bersifat reflektif dengan melakukan tindakan-tindakan tertentu agar dapat memperbaiki dan meningkatkan praktik-praktik pembelajaran di kelas secara lebih profesional. ${ }^{14}$

Adapun subyek dalam penelitian ini adalah peserta didik kelas VI MI 2 Jombang Jember dan peneliti. Ada beberapa ahli yang mengemukakan model penelitian tindakan

${ }^{14}$ Afifiddin dan Beni Ahmad Saebani. 2009. Metodologi Penelitian Kualitatif. (Bandung: CV PustakaSetia). 
dengan bagan yang berbeda, namun secara garis besar terdapat empat tahapan yang lazim dilalui, yaitu perencanaan, pelaksanaan, pengamatan (observasi), dan refleksi.

Prosedur penelitian tindakan kelas ini terdiri dari 4 tahap. Secara rinci prosedur penelitian tindakan ini sebagai berikut: ${ }^{15}$

\section{A. Siklus 1}

1. Perencanaan

1. Merencanakan proses pelaksanaan berfikir dan berbasis masalah dengan metode Means Eands and Analysis Pada pelajaran Matematika

2. Mengembangkan skenario model pembelajaran dengan membuat RPP.

3. Menyusun LOS (Lembar Observasi Siswa)

4. Menyusun kuis (tes)

2. Pelaksanaan tindakan

Kegiatan yang dilaksanakan tahap ini yaitu melaksanakan proses pembelajaran Means Eands and Analysis pada mata pelajaran Matematika direncanakan diantaranya:

5. Guru membuka pelajaran.

6. Guru menyampaikan materi pokok tentang pecahan dengan berbasis heuristik.

7. Guru mendeskripsikan hasil hasil yang diinginkan.

8. Guru meminta siswa untuk membuat sub masalah - sub masalah yang lebih sederhana.

9. Guru meminta siswa untuk mendeskripsikan berdasarkan sub masalah - sub masalah tersebut.

10. Guru meminta siswa mengidentifikasikan perbedaan perbedaan dan menyusun sub masalah - submasalah sehingga terjadi konektifitas.

11. Guru meminta siswa menganalisis cara - cara yang dibutuhkan menyusun sub masalah- subuhkan untuk mencapai hasil yang diinginkan.

12. Siswa mengkontruksi dan menerapkan rencana

13. Siswa melakukan review, evaluasi dan revisi.16

3. Observasi

Kegiatan observasi adalah kegiatan pengamatan selama pembelajaran, yang meliputi observasi terhadap aktivitas guru (peneliti) dan siswa. Masing-masing observer bertugas untuk mengamati aktivitas siswa selama pembelajaran.Aktivitas siswa yang

\footnotetext{
${ }^{15}$ Kunandar. 2011. Langkah Mudah Penelitian Tindakan Kelas Sebagai Pengembangan ProfesiGuru. Jakarta: PT Rajawali Pers.

${ }^{16}$ Miftahul Huda.2013. Model-Model Pengajaran dan Pembelajaran (Yogyakarta : Pustaka Belajar)
} 
diamati pada proses pembelajaran meliputi perhatian terhadap informasi dari guru, mengerjakan problem yang diberikan guru, berdiskusi, dan siswa dapat memecahkan masalah pada soal

4. Refleksi

1. Meneliti hasil kerja terhadap soal yang diberikan.

2. Menganalisis hasil pengamatan untuk membuat kesimpulan sementara terhadap pelaksanaan pengajaran pada siklus I

3. Mendiskusikan hasil analisis untuk tindakan perbaikan pada pelaksanaan kegiatan penelitian dalam siklus II

\section{B. Siklus II}

Setelah melakukan evaluasi tindakan I, maka dilakukan tindakanLangkah-langkah siklus II adalah sebagai berikut:

1 Perencanaan

a. Mengidentifikasi masalah-masalah khusus yang dialami pada siklus sebelumnya.

b. Membuat RPP.

c. Menyusun LOS

d. Menyusun kuis (tes)

2 Pelaksanaan tindakan

Kegiatan yang dilaksanakan tahap ini yaitu Pengembangan rencana tindakan II dengan melaksanakan tindakan upaya lebih meningkatkan semangat belajar siswa dalam proses pelaksanaan Means Eands and Analysis padamata pelajaran matematika materi Pecahan yang telah direncanakan.

\section{Observasi}

4 Refleksi

a. Meneliti hasil kerja siswa terhadap kuis yang diberikan.

b. Menganalisis hasil pengamatan untuk membuat kesimpulan sementara terhadap pelaksanaan pengajaran pada siklus II.

c. Mendiskusikan hasil analisis untuk tindakan perbaikan pada pelaksanaan kegiatan penelitian dalam siklus berikutnya.

Pengambilan data yang digunakan pada penelitian ini ayaitu metode observasi, tes, catatan lapangan dan dokumentasi. Metode observasi digunakan untuk mengamati proses belajar mengajar yang dilakukan guru dan siswa pada saat penerapan strategi. Metode tes sebagai cara untuk mengetahui dan mengukur kemampuan siswa dalam pemecahan masalah matematik melalui penerapan model pembelajaran means end analysis yang berupa soal evaluasi 
yang diberikan oleh guru berupa soal uraian untuk dikerjakan siswa secara mandiripada akhir proses pembelajaranyang bertujuan untuk mengetahui adanya peningkatan yang dapat dilihat dari indikator memahami masalah, merencanakan masalah, dan melaksanakan pemecahan masalah . Metode catatan lapangan digunakan sebagai catatan terurai untuk mencatat kejadiankejadian yang penting dalam proses pembelajaran yang belum ada pada saat observasi . Metode observasi untuk mengamati secara langsung dengan teliti tentang kemampuan siswa dalam pemecahan masalah matematik dengan penerapan model pembelajaran meansends analysis. Dokumentasi pada penelitia ini berupa Rencana PelaksanaanPembelajaran (RPP), identitas siswa antara lain nama siswa, nomor induk siswa, serta buku - buku, arsip atau catatan yang berhubungan dengan yang diteliti dan foto proses berlangsungnya tindakan penelitian.

Data penelitian ini dianalisis mulai dari data awal pada observasi pendahuluan sampai data yang telah dilakukan penerapan model pembelajaran means ends analysis. Data yang diperoleh kemudian dikembangkan menjadirefleksi dan terevisi. Teknik analisis data dimulai dengan reduksi dimana data diambil dari data-data observasi, tes, dan dokumentasi yang ditransfer ke dalam catatan lapangan. Penyajian data yang diperoleh peneliti berupa informasi dari MI 2 Jombang - Jember kemudian peneliti menyusun data tersebut dengan runtut. Penarikan kesimpulan dilakukan pada setiap tindakan yang didapat disimpulkan secara jelas dan dapat diambil tindakan selanjutnya. Penerapan tindakan selanjutnya merupakan revisi dari tindakan sebelumnya sampai pada tujuan penelitian tercapai. Pada analisis hasil lebih menekankan pada penerapan means eand analysis untuk mrningkatkan motivasi siswa dalam pembalajaran. indikatornya meliputi :

1. Kesiapan siswa mengikuti pembelajaran

2. Keaktifan siswa dalam diskusi dengan teman

3. Kesanggupan siswa mengerjakan soal,

4. kemampuan siswa dalam memahami masalah

5. kemampuan siswa dalam merencanakan pemecahan masalah

6. kemampuan siswa dalam melaksanakan pemecahan masalah.

\section{Hasil Penelitian Dan Pembahasan}

Proses kegiatan belajar dan mengajar yang dilakukan guru dan siswa dengan penerapan model pembelajaran means ends analysisuntuk meningkatkan motivasi belajar siswa terjadi selama 2 siklus dan terdapat peningkatan dalam pembelajaran selama 2 siklus terjadi peningkatan kemampuan pemecahan masalah pada siswa. Peningkatan yang terjadi dalam penelitian sesuai dengan indikator pencapaian yang telah disepakati oleh peneliti dan guru matematika. Pencapaian yang meningkat meliputi : 
1. Kesiapan siswa mengikuti pembelajaran

2. Keaktifan siswa dalam diskusi dengan teman

3. Kesanggupan siswa mengerjakan soal

4. Kemampuan siswa dalam memahami masalah

5. Kemampuan siswa dalam merencanakan pemecahan masalah,

6. Kemampuan siswa dalam melaksanakan rencana pemecahan masalah.

\section{Siklus I dan II}

a. Tahap Perencanaan Tindakan

Siklus 1 dan II pelaksanaan pembelajaran berlangsung selama 3 x 35 menit atau $2 \mathrm{x}$ pertemuan. Sebelum kegiatan pembelajaran berlangsung peneliti menyiapkan perangkat pembelajaran dan instrumen penelitian guna memperlancar jalannya penelitan. Perangkat pembelajaran yang disiapkan di antaranya Rencana Pelaksanaan Pembelajaran (RPP), Lembar Kerja Siswa (LKS) dan Instrumen penelitian . Sedangkan instrumen penelitian yang dipersiapkan antara lain lembar observasi kegiatan guru, lembar observasi aktivitas siswa.

\section{b. Tahap Pelaksanaan Tindakan}

Pelaksanaan kegiatan siklus I dan II dilakukan sebanyak dua kali pertemuan dengan pokok bahasan "Pecahan". Setelah membuka pembelajaran dilanjutkan dengan doa, apersepsi tentang pecahan. dan memotivasi siswa, kemudian siswa diberi pre-tes untuk mengetahui kemampuan awalnya.

Dalam pelaksanaan pembelajaran ini peneliti menggunakan metode Mean Eans Analysis. Setelah mendengarkan penjelasan guru tentang Pecahan, kemudian siswa diberi soal untuk di analysis. Hasil pengamatan yang dilakukan siswa di amati dan dicatat. Selanjutnya siswa mengerjakan post- tes secara individu untuk mengetahui peningkatan hasil belajar setelah pelaksanaan tindakan. Hasil post-tes yang diperoleh dapat dilihat pada tabel berikut

\begin{tabular}{|l|l|l|l|l|}
\hline \multirow{2}{*}{ Uraian } & \multicolumn{2}{|l|}{ Siklus I } & \multicolumn{2}{l|}{ Siklus II } \\
\cline { 2 - 5 } & Pre - Tes & Post- & Pre- Tes & Post - \\
\hline
\end{tabular}




\begin{tabular}{|l|l|l|l|l|}
\cline { 2 - 5 } & & Tes & & Tes \\
\hline Jumlah Siswa yang mengikuti Tes & 27 & 27 & 27 & 27 \\
\hline Jumlah Siswa yang Nilainya $>60$ & 9 & 13 & 21 & 26 \\
\hline Persentase & $33,3 \%$ & $51,8 \%$ & $77,8 \%$ & $98,2 \%$ \\
\hline $\begin{array}{l}\text { Jumlah Siswa yang belum tuntas }< \\
60\end{array}$ & 18 & 14 & 6 & 1 \\
\hline Persentase & $66,7 \%$ & $48,2 \%$ & $22,2 \%$ & $1,8 \%$ \\
\hline Nilai Rata - rata & 56,00 & 64,00 & 78,00 & 80,00 \\
\hline
\end{tabular}

Dari hasil post-tes pada tabel di atas ternyata setelah tindakan siklus I jumlah siswa yang tuntas 13 orang $(51,8 \%)$ sedangkan hasil pre-tes siswa yang tuntas 9 orang $(33,3 \%)$. Bila dilihat dari rata-rata hasil tes akhir siswa pada siklus I yang baru mencapai 64,00 secara klasikal hasil tindakan siklus I belum menunjukkan hasil yang memuaskan. Hal ini disebabkan siswa belum begitu jelas dengan prosedur pembelajaran dan masih bingung untuk memecahkan soal pecahan. Kemudian tindakan siklus II jumlah siswa yang tuntas 26 orang $(98,2 \%)$. Bila dilihat dari ratarata hasil tes akhir siswa pada siklus II yang mencapai 80,00 secara klasikal hasil tindakan siklus II telah menunjukkan hasil yang cukup memuaskan. Jika dibandingkan dengan hasil tes akhir pada siklus I yang hanya mencapai 64,00

\section{c. Tahap Observasi}

Observasi dilaksanakan secara langsung bersamaan dengan pelaksanaan tindakan menggunakan lembar observasi untuk aktivitas guru dan aktivitas siswa yang telah peneliti siapkan sebelumnya. Dari hasil observasi tentang aktivitas guru pada siklus I diperoleh data bahwa guru telah melaksanakan pembelajaran sesuai dengan prosedur pembelajaran. Namun masih ada beberapa aspek pembelajaran yang belum dilaksanakan secara optimal seperti : (1).guru tidak menyampaikan pembelajaran dengan jelas, (2) guru kurang memotivasi siswa sehingga siswa kurang bersemangat dan penjelasan guru mengenai materi belum mendalam sedangkan pada siklus II yaitu penggunaan waktu dan pengawasan siswa dalam kerja mengerjakan soal kurang menyeluruh sehingga masih ada siswa yang belum kurang optimal.

Hasil Observasi Menurut Indikator 


\begin{tabular}{|l|l|l|}
\hline Aktifitas Siswa & Siklus I & Siklus II \\
\hline Kesiapan siswa mengikuti pelajaran & $15(65 \%)$ & $24(94 \%)$ \\
\hline $\begin{array}{l}\text { Keaktifan siswa dalam pelajaran } \\
\text { Kesanggupan diswa dalam } \\
\text { mengerjakan soal }\end{array}$ & $5(25 \%)$ & $15(60 \%)$ \\
\hline $\begin{array}{l}\text { Siswa dapat Memahami Masalah } \\
\text { pada soal }\end{array}$ & $10(55 \%)$ & $20(80 \%)$ \\
\hline $\begin{array}{l}\text { Siswa dapat Merencanakan } \\
\text { pemecahan masalah }\end{array}$ & $8(45 \%)$ & $20(80 \%)$ \\
\hline $\begin{array}{l}\text { Siswa Melaksanalan rencana } \\
\text { Pemecahan masalah }\end{array}$ & $15(65 \%)$ & $25(100 \%)$ \\
\cline { 1 - 3 }
\end{tabular}

\section{d. Tahap Refleksi}

Setelah pelaksanaan tindakan siklus I dilaksanakan, peneliti bersama teman melakukan refleksi untuk mengevaluasi aktivitas dan hasil belajar siswa yang diperoleh pada siklus I. Refleksi didasarkan pada nilai tes dan hasil observasi aktivitas guru dan siswa. Dari hasil refleksi diketahui bahwa pada siklus I penggunaan metode pembelajaran means Eands Analysis dalam matematika telah menampakkan hasil yang cukup baik. Namun dalam kegiatan pembelajaran masih banyak hambatan yang dialami oleh guru dan siswa di antaranya: 1) guru belum menjelaskan materi dan prosedur pembelajaran dengan jelas; 2) guru kurang memberi kesempatan siswa untuk bertanya; 3) siswa masih ada yang bingung dalam memecahkan soal; 4) siswa masih ada yang bingung mengenal konsep pecahan. 5) Guru kurang memberi motivasi siswa. Untuk itu perlu dilakukan perbaikan pada siklus berikutnya, dengan mempertimbangkan hasil yang diperoleh pada siklus I. Setelah melaksanaan tindakan siklus II dilaksanakan, peneliti bersama teman sejawat melakukan refleksi untuk mengevaluasi aktivitas dan hasil belajar siswa yang diperoleh pada siklus II. Refleksi didasarkan pada nilai tes dan hasil observasi aktivitas guru dan siswa. Dari hasil refleksi diketahui bahwa pada siklus I penerapan model means eands analysis pembelajaran matematika telah menampakkan hasil yang cukup baik. Namun dalam kegiatan pembelajaran masih banyak hambatan yang dialami oleh guru dan siswa di antaranya: 1) guru belum mengaitkan materi pelajaran dengan materi pelajaran yang 
lain; 2) guru kurang memberi kesempatan siswa untuk menjawab pertanyaan secara merata; 3) siswa masih ada yang belum optimal dalam merencanakan pemecahan soal.

KesimpulanKegiatan pembelajaran matematika dengan penerapan model pembelajaran means ends analysisuntuk meningkatkan motivasi siswa dalam belajardapat meningkatkan hasil belajar matematika pada siswa kelas VI MI 2 Jombang - Jember. Penelitian ini dilakukan dengan kolaborasi dengan guru matematika dan peneliti. peningkatan tersebut dapat dilihat dari indikator sebagai berikut :

Kesiapan siswa mengikuti pelajaran pada siklus I 15 siswa (65\%) pada siklus II ada 24 siswa (94\%), Keaktifan siswa dalam pelajaran pada siklus I 5 Siswa (24\%)pada siklus II ada 15 siswa (60\%), Kesanggupan siswa dalam mengerjakan soal 10 siswa (55\%) pada siklus II ada 20 siswa (80\%), siswa yang memilikikemampuan memahami masalah penelitian pada siklus I ada 10 siswa (55\%), pada siklus II ada 24 siswa (94\%), (b) Siswa yang memiliki kemampuan merencanakan pemecahan masalah siklus I ada 8 siswa (45\%), pada siklus II ada 20 siswa (80 \%), (c) Siswa yang memiliki kemampuan melaksanakan pemecahan masalah pada siklus I ada 15 siswa (65\%), pada siklus II ada $25 \operatorname{siswa}(100 \%)$.

Berdasarkan data di atas dapat dilihat motivasi dapat meningkatan belajar siswa pada siklus I dan siklus II. Yang berdampak pada proses dan hasil belajar, dengan menerapkan metode Means Eand Analysis untuk meningkatkan motivasi siswa dalam belajar.

\section{Daftar Pustaka}

Afifiddin dan Beni Ahmad Saebani. 2009. Metodologi Penelitian Kualitatif. Bandung: CV PustakaSetia.

Baharuddin dan Esa Nurwahyuni. 2007. Teori Belajar dan Pembelajaran. Jakarta: Ar-Ruzz Media.

Djamarah,Syaiful Bahri.2015.Psikologi Belajar. Jakarta : Rineka Cipta

Herdian. 2009. "Model Pembelajaran MEA (Means-Ends Analysis)". https://groups.google.com/forum/?fromgroups=\#!msg/pmt03/LL2hjGJHwtI/fBA KcB5FyPYJ . Diakses tanggal 22 Oktober 2012

Hisyam Zaini.2008Srategi pembelajaran aktif.Yogyakarta: Insan Mandiri.

Khairani, Makmun. 2013. Psikologi Belajar. Yogyakarta: Aswaja Pressindo.

Kunandar. 2011. Langkah Mudah Penelitian Tindakan Kelas Sebagai Pengembangan ProfesiGuru. Jakarta: PT Rajawali Pers. 
Miftahul Huda.2013. Model-Model Pengajaran dan Pembelajaran (Yogyakarta : Pustaka Belajar)

Puspitasari, Itta Denny. 2012. Peningkatan Keterampilan Pemecahan MasalahBelajar Matematika Melalui Strategi Means Ends Analysis. Skripsi.Surakarta: FKIP UMS Tidak terbit ).

Rusfita, Aulia Faradian .2011. Penerepan Model Pembelajaran Means EndsAnalysis untuk Meningkatkan Minat dan Hasil Belajar pada Keliling dan Luas Persegi Panjang. Skripsi. Surakarta : FKIP UMS

Sanjaya Wina. 2009.Kurikulum dan Pembelajaran.Jakarta: Kencana.

Uno, B Hamzah. 2010. Teori Motivasi \& Pengukurannya. Jakarta: Bumi Aksara. 
Khurin'In Ratnasari 
Penerapan Pembelajaran Means Eand Analysis 
Khurin'In Ratnasari 
